\title{
非線形復元力特性を有する制振ダンパーの \\ 構造縮約モデルを用いた最適配置法 \\ OPTIMUM PLACEMENT OF NON-LINEAR DAMPERS IN HIGH-RISE BUILDINGS \\ BY USING REDUCED LOAD AND STRUCTURE MODELS
}

\author{
辻＼cjkstart聖晃 ${ }^{* 1}$, 国分宏樹*2, 吉富信太*3, 竹脇 出*4 \\ Masaaki TSUJI, Hiroki KOKUBU, Shinta YOSHITOMI \\ and Izuru TAKEWAKI
}

\begin{abstract}
A set of reduced models of structures and earthquake loads is proposed for a high-rise building under earthquake ground motions. A reduced structural model is constructed first based on an inverse problem formulation in terms of fundamental eigenfrequency and eigenmode. Then a reduced model of earthquake loads is proposed by requiring the equivalence of displacements at representative nodes in the frame model and the reduced model without inertial and damping terms. These reduced models are used in developing an optimum placement method of nonlinear dampers in high-rise buildings under earthquake ground motions. Numerical response sensitivity by the proposed reduced model is taken full advantage in the optimum placement method. The validity of the proposed method is investigated by the comparison with the results by the original full model.
\end{abstract}

Keywords: Earthquake response, Reduced structural model, Reduced load model, Inverse problem formulation, Structural control, Optimum damper placement

地震時応答, 縮約構造モデル, 縮約外力モデル, 逆問題型定式化, 制振構造, 最適ダンパー配置

\section{1. 序}

高層建物において，地震や風に対する応答低減を目的として制振 部材やシステムを用いた方法が多用されている ${ }^{1-4)}$ 。これらの制振部 材の配置位置により制振効果には大きな差が生じることが知られて おり, 制振部材の最適・有効配置に関する多数の研究が存在する。 辻らは，総ダンパー減衰係数が一定の下で，最大層間変位を目標 值以下とし，構造物の層剛性の総和を最小化する粘性ダンパーの最 適配置手法を提案した ${ }^{5)}$ 。竹脇は粘性ダンパーを設置した構造物に 対して, 非減衰 1 次固有振動数における層間変位の伝達関数の層方 向和や地震時応答を最小化するダンパーの最適配置手法を提案した 6, 7)。中川らは, Poly-linear型履歴ダンパーの最適パラメータを確率 論的地震応答解析に基づき推定し, 構造物の応答を弾性域に留める ダンパーの最適剛性分布の評価法を提案した ${ }^{8)}$ 。また笠井らは種々 のダンパーに対して, 1質点モデルに設置した場合にその構成要素と 制振性能を関連付ける性能曲線を作成し必要ダンパー量を決定した その後, 多質点構造物の高さ及び岡性分布, 地震波の位相やスペク トル形状などを考慮して有効なダンパー配置を決定する手法を提案 している ${ }^{9,10)}$ 。これらの最適・有効配置法には, ダンパーの復元力特 性を線形と近似して行う場合や，最適配置が得られた後に時刻歷応 答解析により妥当性を検討する必要性があるものが多い。前者の場
合は, ダンパーが複雑な非線形の復元力特性を有する場合には適用 が困難である。また, 後者の検討については, 多自由度構造物の時 刻歷応答解析を繰り返し行うには, 多大な時間と計算容量が必要と なり極めて煩雑である。効率的で実用的な方法とするには層方向の 自由度を縮約するなどの方策が必要となる。

自由度を縮約する方法の代表例としてモーダルアナリシスが存在 する。しかし，非線形の復元力特性を有するダンパーを用いて時刻 歴応答解析を行う場合，時々刻々固有值解析を行わなければならず 多大な時間的負荷を要する。また, 自由度の縮約に関する研究には 次のようなものもある。笠井と岩崎は, 1層骨組架構に各種のダンパ 一を組み込んだ場合に，ダンパー取付部材の剛性も考慮可能なせん 断質点系に縮約する方法を示している ${ }^{11)}$ 。そこでは, ダンパー及び 架構からなる制振構造を骨組の静的解析を用いて2自由度に縮約す る方法を示している。しかしながら，その縮約は層内部の自由度を 縮約する方法であり，層方向の縮約に注目する本研究のものとは異 なる。また, $N$ 自由度系の動的解析において, 固有ベクトルを $L(<N)$ 個の直交ベクトル系（Ritzベクトル）の線形結合で近似表現し，運 動方程式の次元を $N$ 自由度から $L$ 自由度に縮約する方法がよく知ら れており ${ }^{12)}$, 多くの汎用構造解析プログラムに組み込まれている。 しかしながら, 精度の高い解析を少ない自由度で実現するためには,

\footnotetext{
*1 京都大学工学研究科建築学専攻 准教授 · 博士 (工学)

$* 2$ 京都大学工学研究科都市環境工学専攻 大学院生 (現 (株)ザイマックス)

*3 京都大学工学研究科建築学専攻 助教 · 博士 (工学)

*4 京都大学工学研究科建築学専攻 教授.工博
}

Assoc. Prof., Dept. of Architecture and Architectural Eng., Kyoto Univ., Dr. Eng. Graduate Student, Dept. of Urban and Environmental Eng., Kyoto Univ.

Assist. Prof., Dept. of Architecture and Architectural Eng., Kyoto Univ., Dr. Eng. Prof., Dept. of Architecture and Architectural Eng., Kyoto Univ., Dr. Eng. 
Ritzベクトルを慎重に選定する必要がある。本論文では, 鈴木らが 風荷重を受ける構造物に対して提案した層方向の自由度の縮約法 ${ }^{13)}$ を地震動を受ける構造物に対して拡張し, 最適配置問題に用いる。 なお，この縮約法では，自由度縮約後のモデルにおけるダンパー量 を決定するために，等価線形化手法を用いているが，縮約後の構造 物に対する応答解析は, 制振ダンパーの非線形復元力特性をそのま ま用いた非線形時刻歴応答解析を行っており, 高い精度での応答評 価が可能である。

本論文の目的は, 非線形の復元力特性を有する制振ダンパーを高 層建物に組み込む際の最適配置法を提案することにある。具体的に は, 多自由度の高層建物を少自由度モデルに縮約し, そのモデルに 対して時刻歴応答解析を行い, 対象とする応答值の感度計算を行う。 その感度解析結果より, 原構造モデルに設置するダンパーの最適配 置を決定する。一般に, 最適化問題において非線形のダンパーを解 析的な数式展開により取り扱うことは極めて困難である。本論文で は, 最適化において時刻歴応答解析による数值微分を用いてそのよ うな困難点を克服する。しかし, 多自由度のモデルに対して時刻歴 応答解析を行うには多大な時間を要する。ここでは, 縮約少自由度 のモデルを用いることにより短時間での解析を可能とする。その結 果, 非線形の復元力特性を有するダンパーの最適配置, ないしはそ の近似解を簡便に決定することが可能となる。

本論文では, 非線形復元力特性を有する制振材料の一例として高 硬度ゴムを取り上げる。この高硬度ゴムは, アクリル系などの粘弾 性材料に比べて温度・振動数依存性が低く, 極微小変形時にはコン クリートに近い剛性を有し, せん断ひずみが $5 \%$ 程度以上になると 鋼材に似た平行四辺形状の復元力ループを描くという特徴を有して いる ${ }^{14), 15)}$ 。この高硬度ゴムを, 履歴依存性を有する弾塑性要素, 振 動数依存性を有する弾性要素, 速度依存性を有する非線形粘性要素 の並列モデルによりモデル化し, 多層せん断質点モデルの主体構造 に組み込む。また，主体構造は弾性範囲にとどまるものとする。

\section{1 次固有振動特性の等価性に基づく縮約構造モデル 2-1 主体構造の縮約}

鈴木らは，逆問題型定式化に基づき多自由度モデルを少自由度の モデルに縮約する方法を提案している ${ }^{13)}$ 。本論文でも，その縮約方 法を用いる (図 1(a)参照)。縮約前のモデルを原モデル, 縮約後のモ デルを縮約モデルと表記する。また一般層の表記を原モデルにおい ては第 $j$ 層, 縮約モデルにおいては第 $i$ 層とする。

縮約モデルの質点位置は, 原モデルの特定の質点位置に対応する ように設定し，この位置を原モデルの縮約代表位置と呼ぶ。縮約モ デルの質量は, 原モデルの縮約代表位置間の各層の質量を, 上層側 の縮約代表位置に単純に加えるものとする。

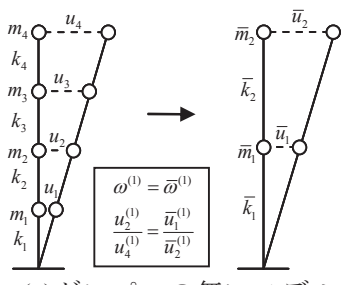

(a)ダンパーの無いモデル

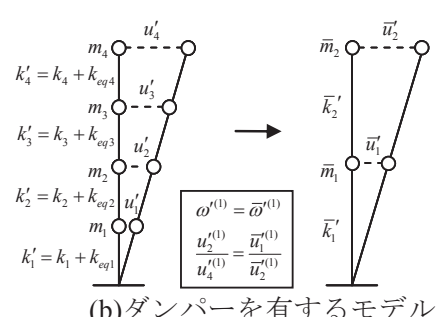

(b)ダンパーを有するモデル
図 1 縮約法の概略図（原モデル : 4 層, 縮約モデル : 2 層)
縮約モデルの剛性は，それを未知量とした 1 次固有振動特性の等 価性条件を逆問題的に解くことにより決定する。 $N$ 自由度原モデル の 1 次固有円振動数と $\bar{N}$ 自由度縮約モデルの 1 次固有円振動数が等 しく, 原モデルの縮約代表位置における 1 次モード成分比と, 縮約 モデルの 1 次モード成分比が等しくなることを等価性条件とすると， 縮約モデルの層剛性は次式となる ${ }^{16)}$

$$
\bar{k}_{i}=\bar{\omega}^{(1) 2} \frac{\sum_{k=i}^{\bar{N}} \bar{m}_{k} \bar{u}_{k}^{(1)}}{\bar{u}_{i}^{(1)}-\bar{u}_{i-1}^{(1)}}(i=1, \cdots, \bar{N}) \quad\left(\bar{u}_{0}^{(1)}=0\right)
$$

ここで， $\bar{m}_{i}, \bar{\omega}^{(1)}$ 及び $\bar{u}_{i}^{(1)}$ は，それぞれ縮約モデルの第 $i$ 層の質量， 1 次固有円振動数及び 1 次固有モードの第 $i$ 成分である。

\section{2-2 主体構造に設置される制振ダンパーの縮約}

本論文では鈴木らの提案した手法 ${ }^{13}$ に基づき, 粘弾性ダンパーや 弾塑性ダンパーなどのひずみ依存性を有するダンパーを用いた場合 に, 各層に設置するダンパーの変形量を主体構造の剛性分布を考慮 した上で決定し，ダンパーを縮約する。図1(b)に制振用ダンパーの 縮約法の概略を示す。

原モデルの第 $j$ 層の剛性 $k_{j}$ に，ダンパーの等価剛性 $k_{e q j}$ を加えた ものを「ダンパー付き原モデルの剛性」とし， $k_{j}{ }^{\prime}$ と表わす。その モデルの 1 次固有周期と 1 次固有モードを別途求め, (1)式に代入し てダンパー付き縮約モデルの層剛性 $\bar{k}_{i}^{\prime}$ を求める。

次に, ダンパー付き縮約モデルの第 $i$ 層における剛性 $\bar{k}_{i}{ }_{i}$ と主体骨 組の縮約モデルの剛性 $\bar{k}_{i}$ の差を縮約モデルに付加されるダンパー の等価剛性 $\bar{k}_{d i}{ }_{d i}=\bar{k}_{i}^{\prime}-\bar{k}_{i}$ とし, 縮約モデルのダンパーの等価剛性に 対応するダンパー量を縮約モデルに付加する。

ダンパーがひずみ依存性を有する場合, 原モデルに設置するダン パーの等価剛性を決めるためには, 第 $j$ 層のダンパーの変形量 $\delta_{\max j}$ および縮約モデルの第 $i$ 層のダンパーの等価剛性 $\bar{k}^{{ }^{\prime}}{ }_{d i}$ に対応するダ ンパー量を決定する際のダンパーの変形量 $\bar{\delta}_{\max i}$ を与えなければな らない。鈴木らは，変形モードを直線形と仮定しているが，一般的 には変形モードは直線形とはならない。そこで，構造物の剛性分布 を考慮し, ダンパーの無い原モデル, 縮約モデルの 1 次固有モード $u_{j}^{(1)}, \bar{u}_{i}^{(1)}$ を用いて $\delta_{\max j}, \bar{\delta}_{\max i}$ を次式により決定する。

$$
\begin{aligned}
& \delta_{\max j}=y_{\max } \frac{u_{j}^{(1)}-u_{j-1}^{(1)}}{u_{N}^{(1)}}, \quad u_{0}^{(1)}=0 \quad(j=1,2, \cdots, N) \\
& \bar{\delta}_{\max i}=y_{\max } \frac{\bar{u}_{i}^{(1)}-\bar{u}_{i-1}^{(1)}}{\bar{u}_{\bar{N}}^{(1)}} \quad(i=1, \cdots, \bar{N})
\end{aligned}
$$

ここで， $y_{\text {max }}$ は別途時刻歴応答解析で求めたダンパーの無い原モデ ルの頂部最大水平変位である。

(2a,b)式では, ダンパーを設置していない構造物の固有モードを用 いている。ダンパーの設置に伴い固有モードも変化するため, (2a,b) 式の固有モードも新たに更新することも考えられるが，ダンパーを 縮約する際のダンパー変形量 $\delta_{\max j}$ および $\bar{\delta}_{\max i}$ を決定するために繰 り返し計算が必要となり, さらにその効果も限定的であることを確 認しているため, 本論文では, $\delta_{\max j}$ および $\overline{\max }_{\max }$ は, ダンパーが無 い場合の固有モードを用いて計算することとする。 


\section{3. 変位の等価性に基づく地震時慣性力の縮約法}

鈴木らは縮約モデルに合わせて風外力を縮約する方法を提案して いる ${ }^{13)}$ 。本論文では地震動を対象としているため, この手法を拡張 して, 地震動作用時に各層に生じる地震時慣性力を縮約する。

まず，地震時慣性力の定義を示す。ある時刻 $t$ において地震動 $\ddot{u}_{g}(t)$ が入力された時の原モデルの運動方程式は次式となる。

$$
\mathbf{M} \ddot{\mathbf{y}}(t)+\mathbf{C} \dot{\mathbf{y}}(t)+\mathbf{K y}(t)=-\mathbf{M r} \ddot{u}_{g}(t)
$$

ここで, $\mathbf{M}, \mathbf{C}, \mathbf{K}$ は原モデルの質量, 減衰, 剛性行列であり, $\mathbf{y}(t)$, $\dot{\mathbf{y}}(t), \ddot{\mathbf{y}}(t)$ は時刻 $t$ における原モデルの地面に対する水平変位べク トル，速度ベクトル，加速度ベクトルである。また， $\mathbf{r}$ は成分がす べて 1 のベクトルである。(3)式の右辺の第 $j$ 成分を時刻 $t$ における 原モデルの第 $j$ 層に作用する地震時慣性力と定義する。

地震時慣性力の縮約法の概念を図 2 に示す。主体構造の剛性によ る復元力のみで外力に抵抗するモデルを考え, このモデルを復元力 抵抗モデルと称す。ある時刻において各層に生じる地震時慣性力を 静的な外力と見なし，復元力抵抗モデルを用いて評価した原モデル の縮約代表位置における変位と, それに対応寸る縮約モデルの変位 が等しいことを等価性条件として地震時慣性力を縮約する。縮約さ れた地震時慣性力を縮約地震時慣性力と表記する。

$N$ 自由度の原モデルの地震時慣性力を $\bar{N}$ 自由度の縮約モデルの 縮約地震時慣性力に縮約する方法を説明する。原モデルの時刻 $t$ に おける地震時慣性力 $-\mathbf{M r} \ddot{u}_{g}(t)$ を「静的に」作用させた時の原モデ ルの各層の水平変位ベクトルを $\mathbf{y}$ とする。時刻 $t$ における地震時慣 性力に対応する縮約地震時慣性力を $\overline{\mathbf{f}}(t)$ とし, 縮約モデルに $\overline{\mathbf{f}}(t)$ を 「静的に」作用させた時の縮約モデルの各層の水平変位ベクトルを $\overline{\mathbf{y}}$ とする。このとき, 縮約前後の両モデルにおける力の釣り合い式 は次式で表わされる。

$$
-\mathbf{M r} \ddot{u}_{g}(t)=\mathbf{K y}, \overline{\mathbf{f}}(t)=\overline{\mathbf{K}} \overline{\mathbf{y}}
$$

$\mathbf{K}, \overline{\mathbf{K}}$ は，原モデル及び縮約モデルの剛性行列であり，本論文では構 造物は弾性範囲にあるとしているので常に一定である。

原モデルの縮約代表位置における水平変位と，それに対応寸る縮 約モデルの水平変位が等しいという等価性条件より縮約地震時慣性 力を導く。ここで， $T_{i j}$ を第 $i$ 行第 $j$ 列成分とする $\bar{N} \times N$ の縮約変換 行列 $\mathbf{T}$ を導入する。原モデルの第 $j$ 層変位と縮約モデルの第 $i$ 層変 位が対応する場合 $T_{i j}=1$ とし, 対応する自由度がない場合には $T_{i j}=0$ とする。 $\mathbf{T}$ を用いると水平変位の等価性条件は次のように表せる。

$$
\overline{\mathbf{y}}=\mathbf{T y}
$$

(4.a,b), (5)式より，縮約地震時慣性力 $\overline{\mathbf{f}}(t)$ は次式で表わされる。

$$
\overline{\mathbf{f}}(t)=\overline{\mathbf{K}} \mathbf{T} \mathbf{y}=-\overline{\mathbf{K}} \mathbf{T} \mathbf{K}^{-1} \mathbf{M r} \ddot{u}_{g}(t)
$$

\section{4. 提案縮約モデルの精度の検証}

前節では復元力抵抗モデルを用いた変位の等価性条件より, 地震 時慣性力を静的な外力と見なし, 縮約地震時慣性力を求める方法を 示した。地震動入力時の時刻歴応答解析を行う際には, 各時刻の動 的な外力についても前節同様に変位の等価性条件が成り立つと仮定 し，(6)式の縮約を各時刻において行う。

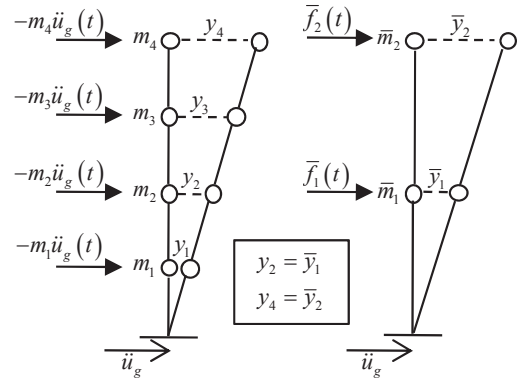

図 2 地震時慣性力の縮約（原モデル：4 層，縮約モデル：2 層）

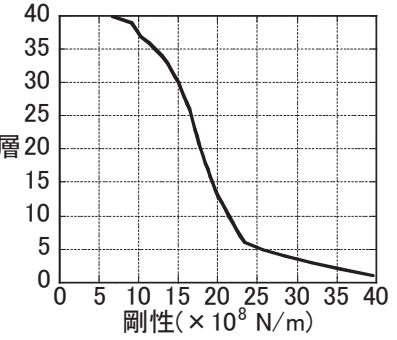

(a)層剛性（原モデル）

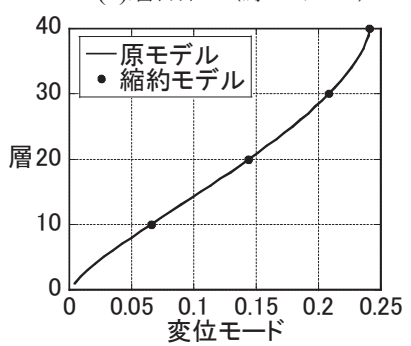

(c)1 次固有変位モードの比較

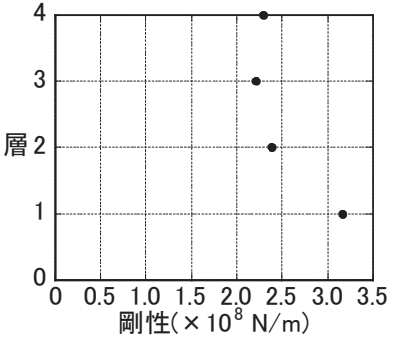

(b)層剛性（縮約モデル）

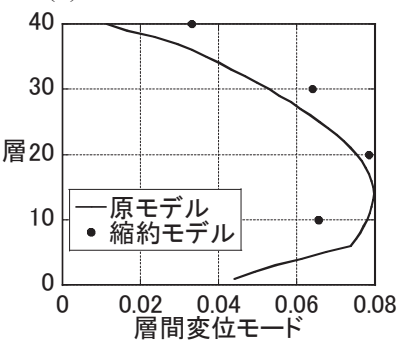

(d) 1 次固有層間変位モードの比較
図 3 原モデルと縮約モデルの剛性と 1 次固有モードの比較

本節では，地震動を受ける構造物に対して上記の縮約法の精度を 検証する。また，ダンパーを設置した場合については，各層同量ず つ設置した場合（以下「均等配置」と称す）を考える。均等配置で ないダンパー配置に関しては 5 節で考察する。ここでは, ダンパー を含む構造物を扱う場合も，(6)式の外力の変換においては主体骨組 のみの剛性を用いる。すなわち, ダンパー配置によらず同じ縮約地 震時慣性力を用いる。なお，縮約する層の地震時慣性力を単純に加 えた縮約モデルに入力する単純和地震時慣性力と 3 節で提案した縮 約地震時慣性力との比較については文献 17)に示されている。

一般的に建物が高層になると，全体曲げの影響により上層部ほど 各層の層間変位に対するダンパーの変形量の割合が低下する。4-1 節，4-2 節においてはこの影響を無視する。すなわち，各層の層間 変位に対するダンパーの変形量を実効率 $\alpha$ と呼び，4-1，4-2 節にお いて実効率 $\alpha$ は全て 1.0 とする。実効率が 1.0 とは層間変位とダン パーの変形量が同じことを意味する。全体曲げを考慮した場合の実 効率への影響については，4-3 節において検討する。

なお，以下では縮約モデルは 4 自由度とし，層間変位と最上層の 加速度の精度を検証した結果のみを示す。縮約モデルを 4 自由度と したのは, 5 節で示すダンパー最適配置の数值例題において, 建物 を層方向に 4 分割し，各区間で同量のダンパーを配置するようなパ ターンを取り上げたためである。縮約モデルの自由度と精度の関係, 及び，ベースシアの精度については，文献 17)に示されている。 


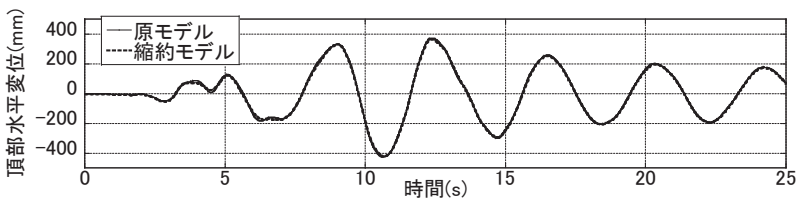

図 4 頂部水平変位の時刻歴（ダンパー無し）

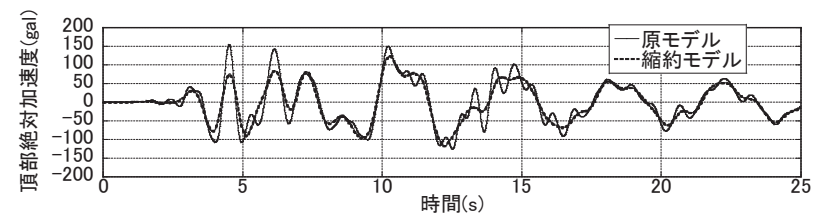

図 5 頂部絶対加速度時刻歴（ダンパー無し）

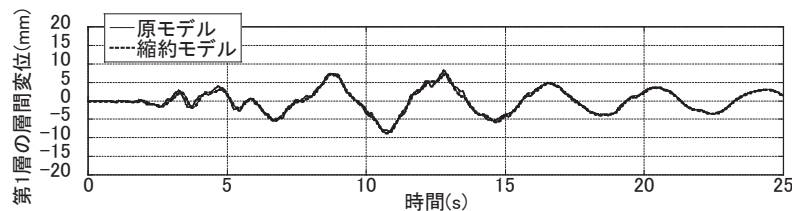

（a）第 1 層の層間変位

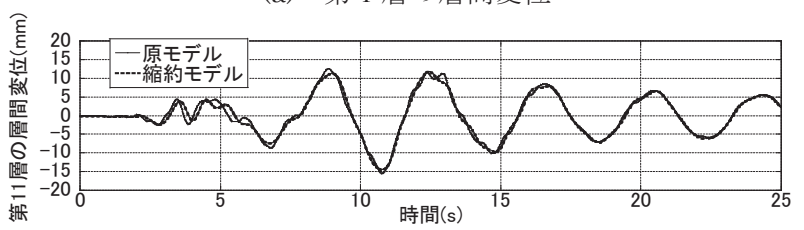

（b）第 11 層の層間変位

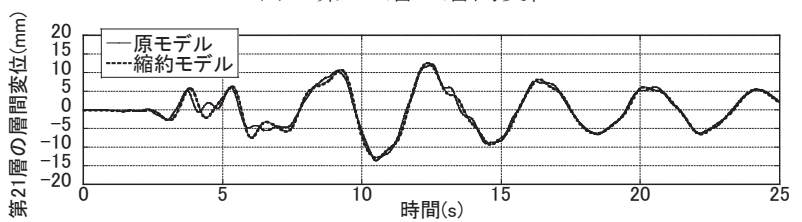

（c）第 21 層の層間変位

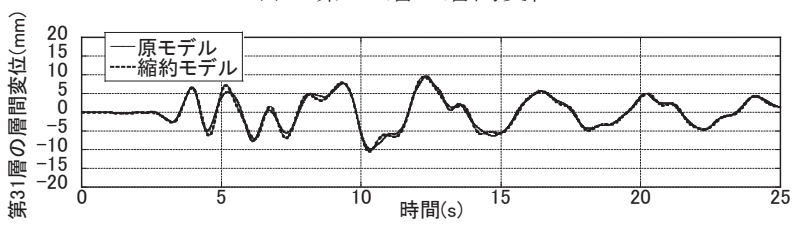

(d) 第 31 層の層間変位

図 6 特定層の層間変位の時刻歴（ダンパー無し）

\section{4-1＼cjkstart現実的な層剛性分布を有する 40 層せん断質点モデル}

原モデルは現実的な層剛性分布を有する 40 層せん断質点モデル と寸る。各層の質量は $1280 \times 10^{3} \mathrm{~kg}$, 固有周期は $4 \mathrm{~s}$, 構造減衰は剛性 比例型とし，1 次の減衰定数は $2 \%$ とする。縮約モデルは 4 自由度の せん断質点モデルとし，第 10, 20,30，40 層を縮約代表位置とする。 構造減衰は剛性比例型とし, 1 次の減衰定数は原モデルと同じく $2 \%$ とする。原モデル及び縮約モデルの層剛性分布及び变位の 1 次モー ドを図 3 に示す。

地震動は Newmark と Hall の設計用応答スペクトル ${ }^{18)}$ から作成し た模擬地震動 (レベル 1 相当, 以下模擬地震動と呼ぶ) 10 波を用い, 頂部水平変位, 頂部絶対加速度及び特定層（原モデルの第 $1,11,21$, 31 層)の層間変位を検討の対象とする。本例では縮約モデルの第 $i$ 層 の層間変位は原モデルの第 $10 \times(i-1)$ 層と第 $10 \times i$ 層の水平変位の差 に相当している。従って, 原モデルの特定層の層間変位を検討する 場合, 原モデルの第 $\{(i-1) \times 10+1\}$ 層の層間変位と縮約モデルの第 $i$
層の層間変位を $\left(u_{(i-1) \times 10+1}^{(1)}-u_{(i-1) \times 10}^{(1)}\right) /\left(u_{i \times 10}^{(1)}-u_{(i-1) \times 10}^{(1)}\right)$ 倍したものを比較す る $(i=1,2,3,4)$ 。

図 4 6 に, 模擬地震動 1 波が入力された場合の時刻歴応答解析結 果を示す。図 4, 6 より頂部水平変位及び特定層の層間変位について は縮約モデルによって精度良く表現できているといえる。図 5 より， 頂部絶対加速度については, 全体的には精度よく表現できていると 考えられるが，ピーク值に誤差が生じている。これは，本縮約法で は代表点での 1 次モードを等価にしているが，高次モードの影響も 大きいことが原因であると考えられる。

\section{4-2 高硬度ゴムダンパーが設置された 40 層せん断質点モデル}

原モデルに文献 14)の高硬度ゴムダンパーを設置する場合を扱う。 高硬度ゴムダンパーの力学モデルを用いると, 第 $j$ 層の高硬度ゴム ダンパーの断面積を $S_{j}\left[\mathrm{~mm}^{2}\right]$, 厚さを $d_{j}[\mathrm{~mm}]$ としたときの第 $j$ 層ダ ンパーの等価剛性 $k_{e q j}[\mathrm{~N} / \mathrm{mm}]$ は次式で表わされる ${ }^{19)}$ 。

$$
k_{e q j}=\frac{S_{j}}{d_{j}}\left(0.32 \gamma_{\max j}^{-0.62}+0.10 \gamma_{\max j}^{-0.66}\right)
$$

ここで, $\gamma_{\max }$ は第 $j$ 層の高硬度ゴムの最大せん断ひずみとする。 $\gamma_{\max j}$ は第 $j$ 層のダンパーの変形量 $\delta_{\max j}$ をダンパー厚さ $d_{j}$ で除した もので, $\gamma_{\max j}=\delta_{\max j} / d_{j}$ の関係と $(2 \mathrm{a})$ 式より次式を得る。

$$
\gamma_{\max j}=\frac{u_{j}^{(1)}-u_{j-1}^{(1)}}{u_{N}^{(1)}} \frac{y_{\max }}{d_{j}}
$$

高硬度ゴムダンパーが設置された 40 自由度せん断質点モデルを 4 自由度モデルに縮約する場合を例として述べる。高硬度ゴムダンパ 一を制振壁型ダンパーとして組み込むことを想定し，制振壁 1 枚当 たりの高硬度ゴムの形状は厚さ $15 \mathrm{~mm}$, 面積 $0.96 \mathrm{~m}^{2}$ とする。以後, 原モデルに設置するダンパー量は断面積で表現する。縮約モデルの 第 $i$ 層に付加されるダンパーの断面積, 厚さ及び最大せん断ひずみ を $\bar{S}_{i}, \bar{d}_{i}, \bar{\gamma}_{\max i}$ とする。以下では 2-2 節の手法に基づき, 縮約モデ ルに付加すべきダンパーの断面積を求める手順について示す。

まず，(1)式より，縮約モデルの第 $i$ 層のダンパーの等価剛性 $\bar{k}_{d i}$ を 求める。縮約モデルに設置するダンパーの厚さは縮約層数 $n$ 分を加 える。すなわち，原モデルの各層に設置しているダンパーの厚さをす心゙ て $d$ と寸ると, $\bar{d}_{i}$ は次式から求められる。

$$
\bar{d}_{i}=n d
$$

40 自由度のモデルを 4 自由度のモデルに縮約する場合（縮約代表位 置は 4-1 節と同様) $n=10$ であり, $\bar{d}_{i}=10 d$ となる。 $\bar{\gamma}_{\max i}$ は $\bar{d}_{i}$ 及び (2b)式を用い次式で表わされる。

$$
\bar{\gamma}_{\max i}=\frac{\bar{u}_{i}^{(1)}-\bar{u}_{i-1}^{(1)}}{\bar{u}_{\bar{N}}^{(1)}} \frac{y_{\max }}{\bar{d}_{i}}
$$

$\bar{k}_{d i}, \bar{\gamma}_{\max i}, \bar{d}_{i}$ を(7)式に代入することにより, 断面積 $\bar{S}_{i}$ が得られる。

上記で求めた断面積 $\bar{S}_{i}$ を2-1 節で縮約した縮約モデルの第 $i$ 層に 設置し, 時刻歴応答解析を行う。ここでは, 原モデルの各層に設置 するダンパー量が全て同じ場合を検証する。

各層にダンパーを $5 \mathrm{~m}^{2}$ ずつ設置した場合を考える。原モデル及び 縮約モデルに模擬地震動 1 波を入力した場合の時刻歴応答解析結果 を図 7〜9に示す。ダンパーが無い場合と同様, 頂部水平変位及び特 


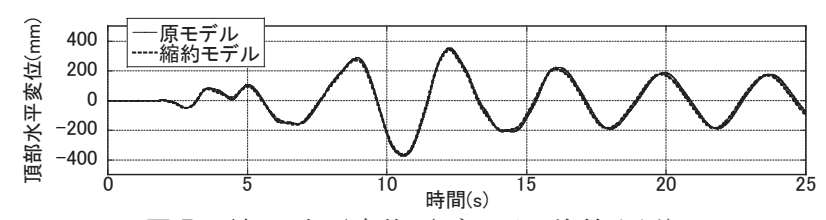

図 7 頂部の水平変位（ダンパー均等配置）

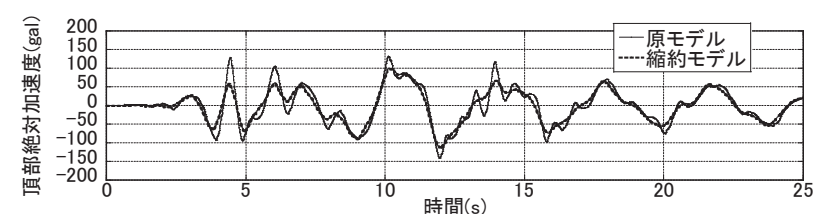

図 8 頂部の絶対加速度 (ダンパー均等配置)

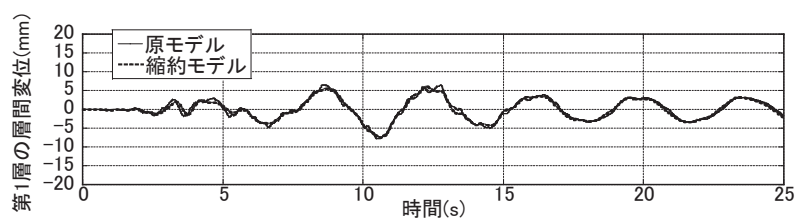

（a）第 1 層の層間変位

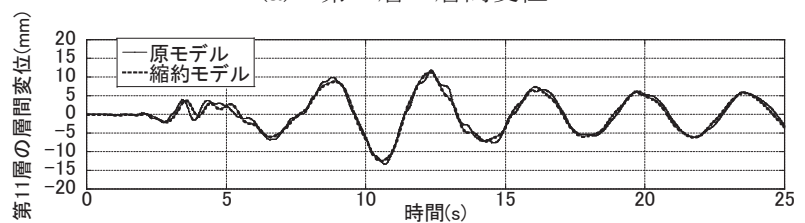

（b）第 11 層の層間変位

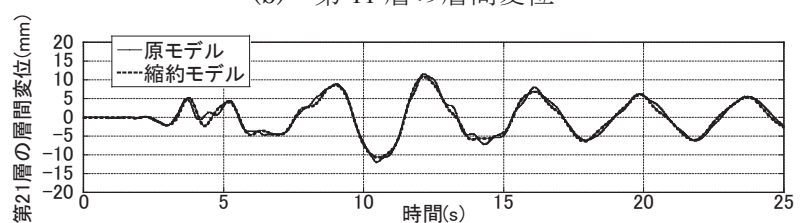

（c）第 21 層の層間変位

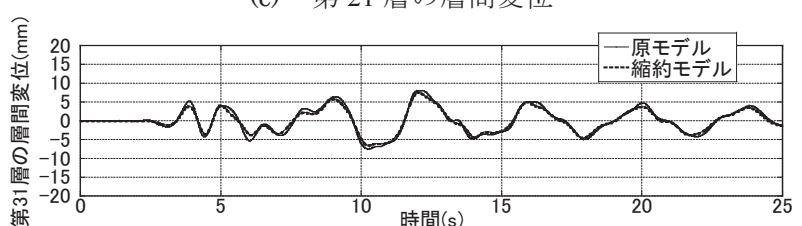

(d) 第 31 層の層間変位

図 9 特定層の層間変位の時刻歴（ダンパー均等配置）

定層の層間変位に関しては縮約モデルを用いて原モデルの解析結果 を精度良く表現できることがわかる。頂部絶対加速度については， ピーク值において精度が低下している。これはダンパーが無い場合 に述べた通り，高次モードの影響が大きいことが原因であると考え られる。

図 10 に原モデルの各層に設置するダンパー量を 0 500 $\mathrm{m}^{2}$ の範囲 で変化させた時の各最大応答值の変動を示す。また, 図 11 に原モデ ルの総ダンパー断面積が $0 \mathrm{~m}^{2}, 250 \mathrm{~m}^{2}$ 及び $500 \mathrm{~m}^{2}$ の場合の原モデル 及び縮約モデルの最大層間変位分布を示す。なお，ここでの「最大 応答值」とは, 入力用模擬地震波 10 波のそれぞれに対する最大応答 值の平均值を示している。頂部最大水平変位及び特定層の最大層間 変位に関しては原モデルの応答低減率を縮約モデルを用いて定量的 に表現できていることがわかる。頂部最大絶対加速度に関しては, 時刻歴応答解析結果のピーク值に差があるため最大応答值に差が見 られるが，定性的には原モデルの応答低減率は縮約モデルを用いて

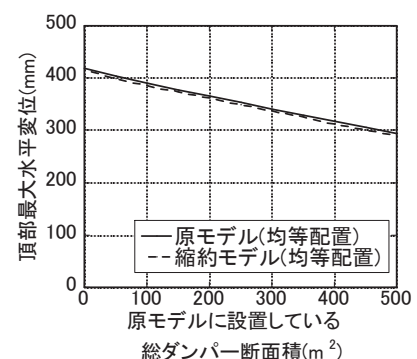

(a)頂部最大水平変位

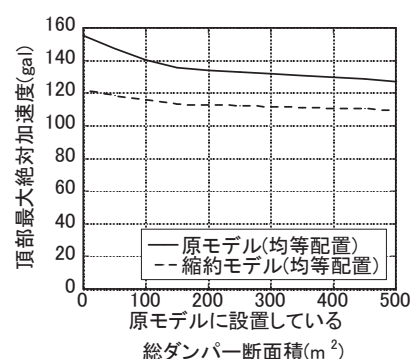

(b)頂部最大絶対加速度
図 10 ダンパー量の変動に対する各最大応答值の変動

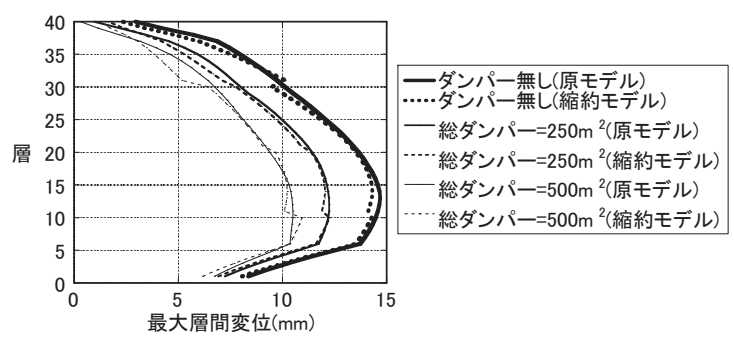

図 11 最大層間変位分布（原モデル及び縮約モデル）

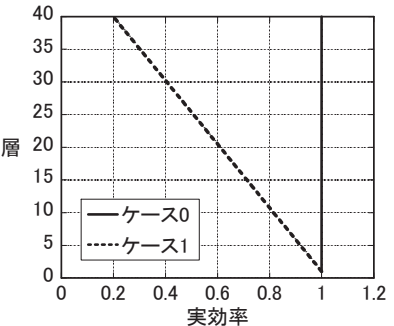

図 12 想定する実効率

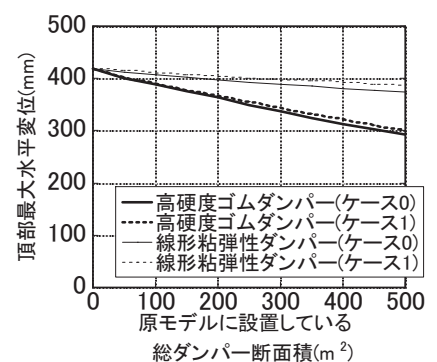

(a) 頂部最大水平変位

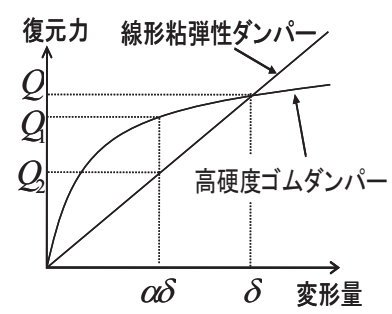
ダンパーの復元力特性

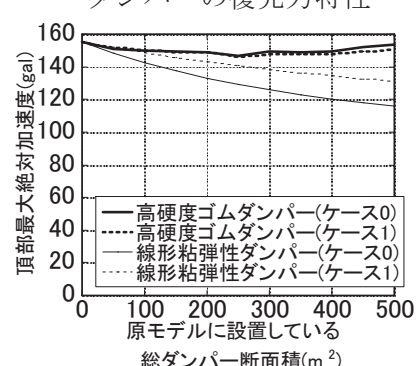

(b) 頂部最大絶対加速度
図 13 高硬度ゴムと線形粘弹性

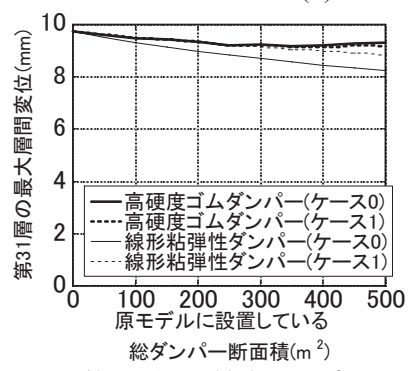

(c) 第 31 層の最大層間変位

図 14 最大応答值の変動

表現できているといえる。本論文の目的は，原モデルに設置するダ ンパー配置の最適化を縮約モデルを用いて行うことにあり，原モデ ルのダンパー量の変動に対する応答值の変動を縮約モデルを用いて 定性的に表現できているため, 縮約モデルを用いた最適配置を近似 的に行うことは可能であると考えられる。 


\section{4-3＼cjkstart全体曲げの影響を考慮した実効率の導入}

前節までは, ダンパーの実効率は各層全て 1.0 とした。しかし， 高層の建物になると全体曲げの影響により上層部ほど実効率が低下 する。本節では全体曲げの影響による実効率の低下が解析結果に与 える影響について検討寸る。高硬度ゴムダンパーを用いた場合と， 線形粘弾性ダンパーを用いた場合とを比較する。線形粘弾性ダンパ 一の剛性, 減衰係数としてはアクリル系粘弾性ダンパーの等価剛性, 等価減衰係数を用いる。アクリル系粘弾性ダンパーは振動数依存性 及び温度依存性を考慮する必要がある。本構造物の 1 次固有周期 (ダ ンパーが無い場合) が $4.0 \mathrm{~s}$ であることから, 振動数については $0.25 \mathrm{~Hz}$ を採用, 温度については $20^{\circ} \mathrm{C}$ を採用する。この場合の断面積 $1 \mathrm{~m}^{2}$, 厚さ $15 \mathrm{~mm}$ のアクリル系粘弾性ダンパーの剛性, 減衰係数はそれぞ れ $6.67 \times 10^{6} \mathrm{~N} / \mathrm{m}, 2.97 \times 10^{6} \mathrm{Ns} / \mathrm{m}$ である。

ダンパーの実効率としては, 図 12 に示寸各層全て 1.0 の場合（以 下，「ケース $0 」 と$ 称す）と，第 1 層を 1.0 ，第 40 層を 0.2 とし，そ れらを直線で結んだ場合（以下，「ケース1」と称す）とを比較する。 図 14 にそれぞれのケースについて, 高硬度ゴムダンパー, アクリル 系粘弾性ダンパーを均等配置した場合の頂部最大水平変位，頂部最 大絶対加速度及び実効率の差が大きい第 31 層最大層間変位の変動 を示す。アクリル系粘弾性ダンパーの場合，ケース０とケース 1 の 最大応答值の差が大きいのに対し，高硬度ゴムダンパーの場合，各 ケースの最大応答值の差は小さい。これは, 図 13 に示すような両ダ ンパーの復元力特性の違いに起因すると考えられる。ダンパー変形 量が $\delta$ の時に, 両ダンパーの復元力がともに $Q$ であるとする。曲げ を考慮した実効率 $\alpha(<1.0)$ を用いると, 層間変位が $\delta$ の時にダンパ 一変形量は $\alpha \delta$ となり，高硬度ゴムダンパー及びアクリル系粘弾性 ダンパーの復元力はそれぞれ $Q_{1}, Q_{2}\left(Q>Q_{1}>Q_{2}\right)$ となる。従って, 曲げの影響を考慮した実効率の導入によりダンパーの変形量が低減 したとしても, 高硬度ゴムダンパーはアクリル系粘弾性ダンパーに 比べ復元力に与える影響は小さいため, 図 13 に示すような性質を示 したと考えられる。以上より，高硬度ゴムダンパーにおいては実効 率の変化の影響が小さいことを考慮して，5節で行う最適化では, 実効率を全て 1.0 とした場合を扱う。

\section{5. 縮約構造モデルを用いたダンパーの最適配置}

\section{5-1ダンパー最適配置問題および解法の特徵}

質量，剛性，減衰係数が与えられた $N$ 層せん断モデルの主体構造 に対して, 総量の指定された高硬度ゴムダンパーを地震時最大応答 を最小化するように配置する次のような問題を扱う。

\begin{tabular}{ll}
\hline Find & $\mathbf{S}=\left\{S_{1}, \ldots, S_{N}\right\}$ \\
to minimize & $R_{\max }(\mathbf{S})$ \\
subject to $\quad$ & $\sum_{j=1}^{N} S_{j}=S_{\text {total }}$
\end{tabular}

ここで $R_{\max }(\mathbf{S})$ は変位や加速度などの地震時最大応答, $S_{\text {total }}$ はダンパ 一総量の指定值とする。

これまでに, 建築構造物の地震時の応答などを最小化するような ダンパー最適配置問題について, ダンパー総量を 0 から漸増させて 各ダンパー総量レベルに応じた最適ダンパー配置を求める方法が提

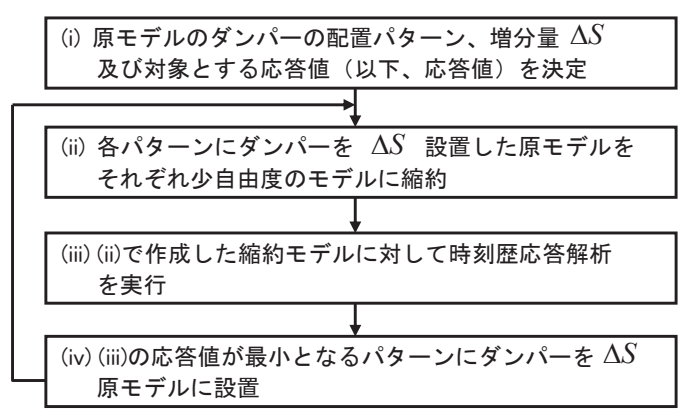

図 15 ダンパーの最適配置を決定するフローチャート

案されている7)。この手法においては, 設計変数である各層ダンパ 一量に関する目的関数の 1 次及び 2 次の感度を解析的に数式で表現 し, ダンパー設置層の 1 次の感度式（最適性条件）を連続的に満足 させるように工夫されている77。

本論文においては，非線形ダンパーを有する建物の時刻歴応答を 対象とするため, 想定される計算負荷の増大や解の非単調性の問題 を考慮して，上記の手法を直接用いることはできない。本論文で提 案する手法の特徵は, (1)感度解析に縮約モデルを用いる点, (2)感度 を数值差分により評価する点，(3)1 次感度のみを用いる点にある。

計算負荷については, 上記の特徵(1), (3)により大幅に低減できる。 例えば, 次節以降で扱う 40 自由度の原モデル及び 4 自由度の縮約モ デルに対して前述の模擬地震動を入力し 10 波の平均をとる場合, 所 要時間は原モデルでは 5 分, 縮約モデルでは 30 秒である。また，上 記(2)により, ダンパーの付加量と差分計算時の増分量を等しくする ことにより, 精度を確保しつつ 1 回のダンパーの更新量を大きくし て更新回数を減らすことができる。

解の非単調性については, 上記の特徽(2)によりある程度回避する ことができる。次節に具体的なアルゴリズムを示す。

\section{$5-2$ 最適化アルゴリズム}

図 15 に示寸フローチャートに従って最適化を行う。

(i)まず，原モデルに設置するダンパーの配置パターンを決める。す なわち, 原モデルの第 $1 \sim p$ 層, 第 $p+1 \sim q$ 層, $\cdots$, 第 $v+1 \sim$ $N$ 層に設置するダンパー量をそれぞれ等しいとし, 配置パターン をそれぞれ pattern 1, pattern 2,・・・, pattern X と呼ぶ。このパ ターンは設計者が自由に選択可能である。各ダンパー量の初期值 は 0 とする。次に, 感度計算で用いるダンパーの増分量 $\Delta S$ を決 める。最後に，最小化したい応答值を決める。

(ii)現在のダンパー量に対して, (i)で設定した各パターンにダンパー の増分量 $\Delta S$ を付加した場合について，それぞれ少自由度のモデ ルに縮約する。その際，各パターンに含まれる層を 1 層分に縮約 する。従って，合計 $\mathrm{X}$ 個の縮約モデルを作成する。

(iii) (ii)で作成した各縮約モデルに対して時刻歴応答解析を実行す る。合計で X 回時刻歴応答解析を行う。

(iv) (iii)で行った解析のうち, 対象とする応答值が最小となる（感度 が最大となる）パターンにダンパーを $\Delta S$ だけ原モデルに設置す る。これを，新たな状態として(ii)に戻り (ii)〜 (iv)を繰り返す。こ の(ii)〜(iv)を最適配置を決定する上での 1 ステップとする。

\section{$5-3$ 数值例題}

本節では，5-2 節で示した最適化アルゴリズムを用いた数值例を 


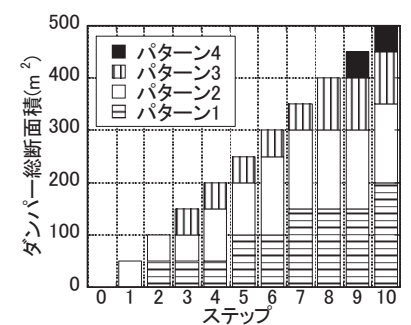

(a) Method R

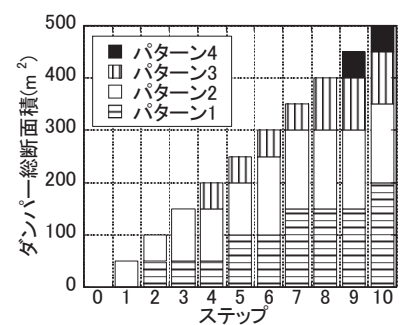

(b) Method F
図 16 ダンパー配置分布図（頂部最大水平変位を最小化）

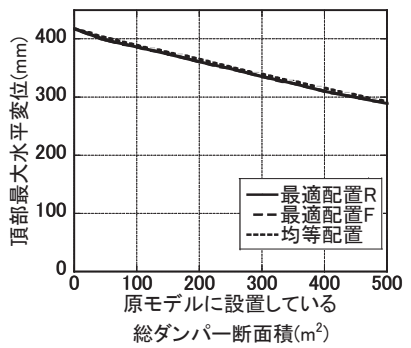

(a)頂部最大水平変位 図 17 最大応答值（原モデル）

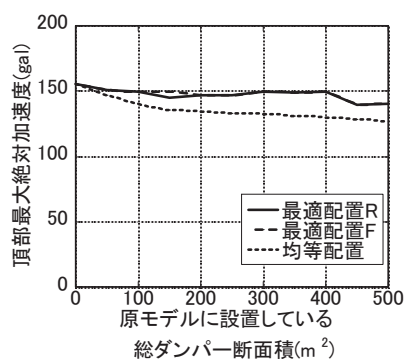

(b)頂部最大絶対加速度

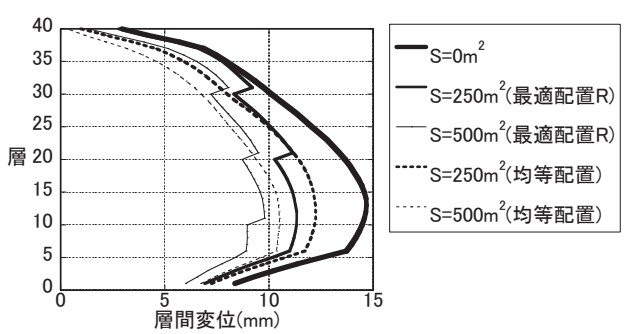

図 18 最大層間変位分布（原モデル）

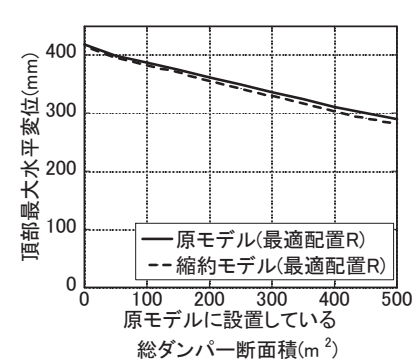

(a)頂部最大水平変位

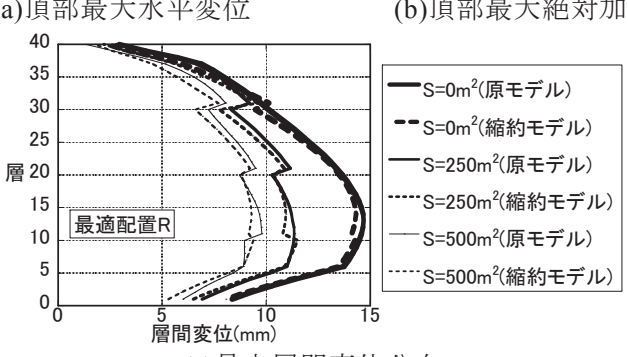

(c)最大層間変位分布

図 19 原モデルと縮約モデルの比較（最適配置 $\mathrm{R}$ )

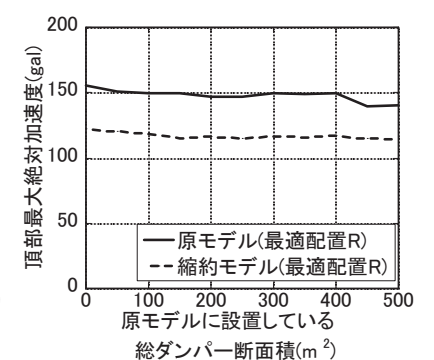

(b)頂部最大絶対加速度
示す。構造物モデル, 入力地震動, 及びダンパーは前節で用いたも のと同じものとする。ダンパーの配置パターンは第 $1 \sim 10$ 層, 第 11 ～20 層, 第 21〜30 層, 第 31〜 40 層それぞれの各層に同量ずつ設置 寸るものとし，それぞれに配置するパターンを pattern 1, pattern 2, pattern 3, pattern 4 と呼ぶ。1 ステップで増加させるダンパー総量の
増分量は $\Delta S=5.0 \mathrm{~m}^{2}$ とする。尚, 別途ダンパーの増分量を $\Delta S=0.5,1.0,2.5,5.0 \mathrm{~m}^{2}$ とした場合の感度解析を行い, ダンパーの増 分量の違いが感度に与える影響が小さいことを確認している。従っ て, ダンパーの増分量の違いが最適結果に与える影響は小さいと考 えられる。

対象応答量を頂部の最大水平変位(模擬地震波 10 波に対する最大 值の平均值, 以下同じ), 最大層間変位及び最大絶対加速度とした 3 つのケースを考え, 各ケースともに 5-2 節のフローチャートの(ii) (iv)を 10 ステップ行う。この場合, 最終的に原モデルに設置する高 硬度ゴムダンパーの総断面積は $500 \mathrm{~m}^{2}$ となる。

以下では, 縮約モデルによる感度解析を用いる方法の妥当性を検 証するため, 縮約モデルを用いず原モデルによる感度解析を用いた 最適化も行い, 両手法により得られたダンパー配置を比較する。感 度解析に縮約モデルを用いる方法を Method R, 縮約モデルを用いな い方法を Method F と呼ぶ。また, Method R を用いて得られたダン パー配置を「最適配置 $\mathrm{R}\rfloor$, Method $\mathrm{F}$ を用いて得られたダンパー配 置を「最適配置 $\mathrm{F} 」$ と呼ぶ。さらに, 本提案手法を用いて得られた 最適配置の妥当性を検討するために, 全層に同断面積ずつダンパー を設置した場合（均等配置）との応答值の比較も併せて行う。

なお, 最適配置 $\mathrm{F}$ と最適配置 $\mathrm{R}$ は, 後述するように一致する場合 もあれば異なる場合もある。両者が一致しない場合, 最適配置 R は, 最適配置 $\mathrm{F}$ に対する近似解であると考えることができる。

ダンパーの最適配置は, ダンパーの種別, 構造物の層数や層剛性 分布, 目的関数や制約条件とする応答量の種別, 入力外乱の種別や レベルにより異なるため, 本節で示す最適なダンパー配置の特徴そ のものには一般性はない。また, 縮約モデルを用いずに最適配置を 求めた場合と, 縮約モデルを用いて最適配置を求めた場合の, ダン パー配置にみられる定量的, 定性的な違いについても, 設定する数 值例題の設定条件に依存寸る。

\section{5-3-1＼cjkstart頂部最大水平変位を最小化する場合}

図 16 に頂部の最大水平変位を最小化するダンパー配置を示す。図 16 より, 最適配置 $\mathrm{R}$ と最適配置 $\mathrm{F}$ はほぼ一致していることがわかる。 従って, 頂部の最大水平変位を最小化する場合, Method R の妥当性 が例証されたといえる。

次に, 図 17,18 に最適配置 $\mathrm{R}$ 及び最適配置 $\mathrm{F}$ の場合と, 均等配 置の場合の原モデルにおける各応答值を示す。図 17(a)より両最適配 置と一様配置の場合で, 本節で最小化の対象にしている頂部最大水 平変位はほぼ同じであることがわかる。しかし, 図 18 より両最適配 置の方が均等配置に比べて最大層間変位の最大值（第 13 層付近）は 小さいことがわかる。即ち, 本最適配置法を用いることにより, 各 層の最大層間変位の最大值を小さくしつつ, 頂部最大水平変位を最 小化することが可能となる。一般的に, 地震動に対する応答低減を 目的としてダンパーを設置する場合, 最大層間変位の最大值を小さ くすることに重点が置かれるため, 本最適化法は有効であると考え られる。

また, 頂部最大水平変位を最小化する場合, 層間変位が大きい層 にダンパーが配置される結果となっている。これは本論文で扱って いる高硬度ゴムダンパーは剛性付加型ダンパーとエネルギー吸収型 ダンパーの性質を併せ持ったものであり, エネルギー吸収型ダンパ 一は層間変位の大きい層に設置するのが効果的と考えられているこ 


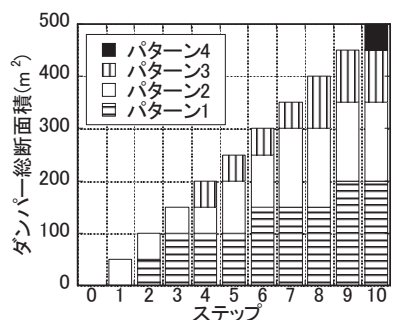

(a) Method R

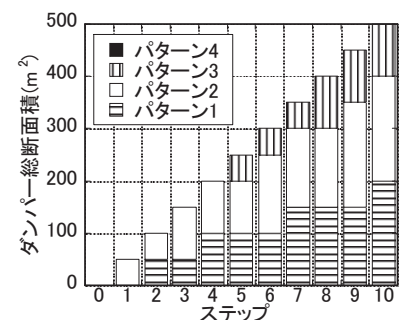

(b) Method F
図 20 最適ダンパー配置分布図（最大層間変位の最大值を最小化）

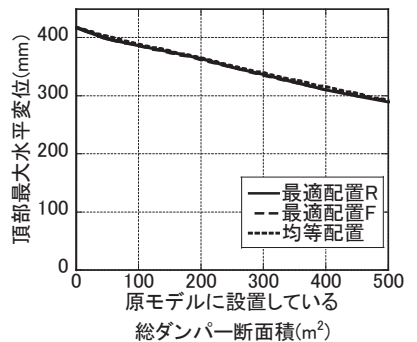

(a)頂部最大水平変位

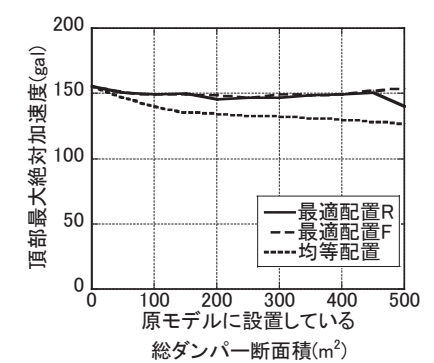

(b)頂部最大絶対加速度
図 21 最大応答值（原モデル）
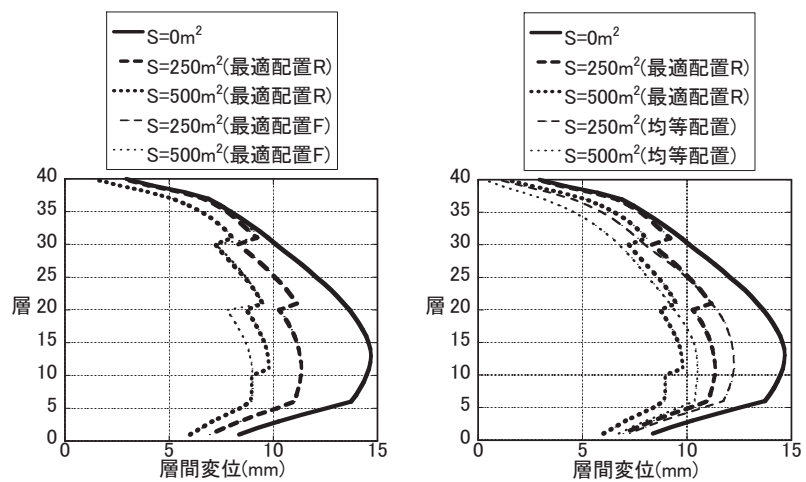

(a)最適配置 $\mathrm{R}$ と最適配置 $\mathrm{F}$ の比較 (b)最適配置 $\mathrm{R}$ と均等配置の比較 図 22 最大層間変位分布（原モデル）

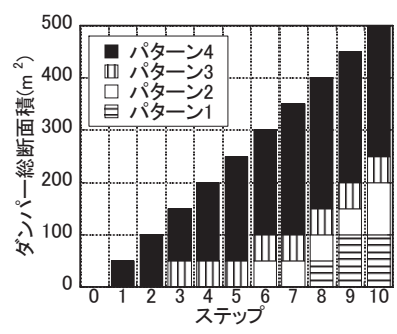

(a) Method R

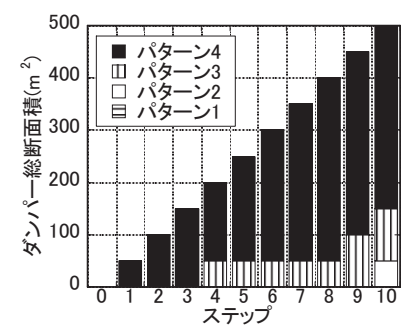

(b) Method F
図 23 ダンパー配置分布図（頂部最大絶対加速度を最小化）

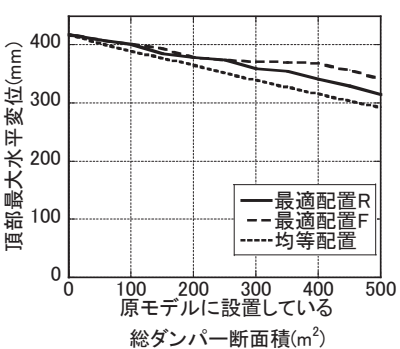

(a)頂部最大水平変位

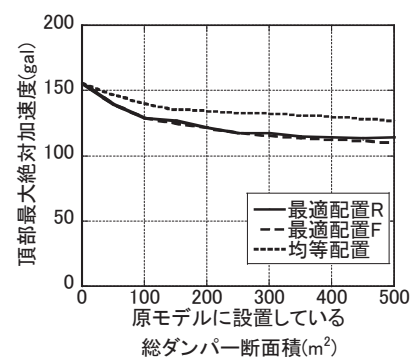

(b)頂部最大絶対加速度
図 24 最大応答值（原モデル）
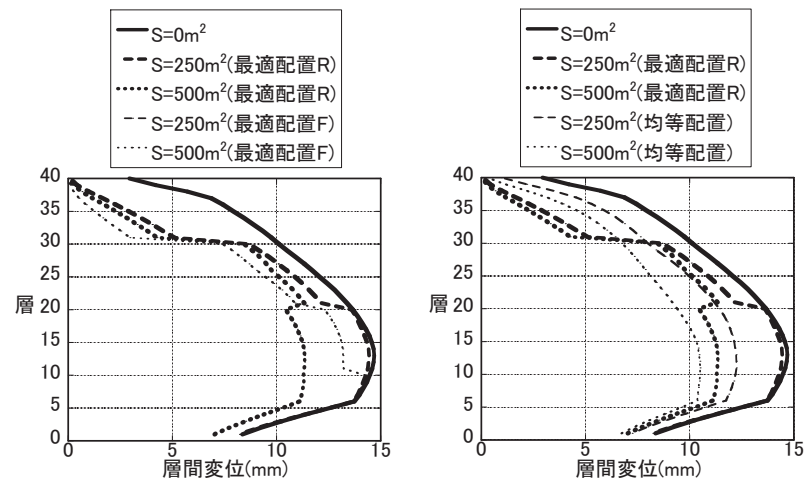

(a) 最適配置 $\mathrm{R}$ と最適配置 $\mathrm{F} の$ 比較 (b) 最適配置 $\mathrm{R}$ と均等配置の比較 図 25 最大層間変位分布（原モデル）

とに対応している。ダンパーを均等配置した場合の縮約モデルの精 度検証は 4 節において行っており, 以下ではダンパー配置が均等で ない場合の縮約モデルの精度について述べる。図 19 に最適配置 R を原モデルと縮約モデルに配置した場合の応答值を示す。頂部最大 水平変位及び最大層間変位については定量的に原モデルの応答值を 表現できている。従って, 均等配置ではないダンパー配置において も, 本縮約法は有効であるといえる。

\section{5-3-2 最大層間変位の最大値を最小化する場合}

本節では, 最大層間変位が最大の層（以下「対象層」と呼ぶ）の 最大層間変位を最小化する場合を考える。

図 20 に対象層の最大層間変位を最小化するダンパー配置を示す。 また, 図 21,22 に, 原モデルに対して, 最適配置 $\mathrm{R}$ 及び最適配置 $\mathrm{F}$ とした場合と，均等配置とした場合の各応答值を示す。

図 20 より, 1, 2, 5, 7, 8 ステップにおいては, 最適配置 $\mathrm{R}$ と最適配 置 $\mathrm{F}$ は一致している。その他のステップにおいて多少配置は異なる ものの, 図 22(a)に示すように両方法での配置において対象層の最大 層間変位にはほとんど差が見られない。対象層の最大層間変位を最 小化する場合においても本最適配置法は有効であるといえる。また Method R, F ともに各ステップにおいて対象層を含むパターンにダ

ンパーが設置される結果となっている。これは, 高硬度ゴムダンパ 一の剛性付加要素にダンパー設置層の層間変位を大きく減ずる効果 があることによると考えられる。また, 図 22(b)において最適配置 $\mathrm{R}$ と均等配置を比較すると, 最適配置 $\mathrm{R}$ の方が対象層の最大層間変位 を大きく減じることが可能であることがわかる。

5-3-1 節で示した頂部最大水平変位を最小化する最適配置（図 16） と比較すると, 図 20 の最適ダンパー配置ははほぼ同じであることが わかる。これは, 5-3-1 節でも示した通り, 高硬度ゴムダンパーのエ ネルギー吸収要素が層間変位の大きい層で効果を発揮することが理 由であると考えられる。

\section{5-3-3 頂部最大絶対加速度を最小化する場合}

図 23 に, 頂部最大絶対加速度を最小化するダンパー配置を示す。 また, 図 24,25 に, 原モデルに対して, 最適配置 $\mathrm{R}$ 及び最適配置 $\mathrm{F}$ とした場合と，均等配置とした場合の各応答值を示す。

図 23 より, 1, 2, 4, 5 ステップにおいては, 最適配置 $\mathrm{R}$ と最適配置 F は一致している。その他のステップにおいて多少配置は異なるも のの, 図 24(b)に示すように両最適解において頂部最大加速度にはほ とんど差が見られない。これは第 5 ステップ（総ダンパー断面積 $250 \mathrm{~m}^{2}$ ）を超えた範囲では複数の層のダンパー量に対する頂部最大 


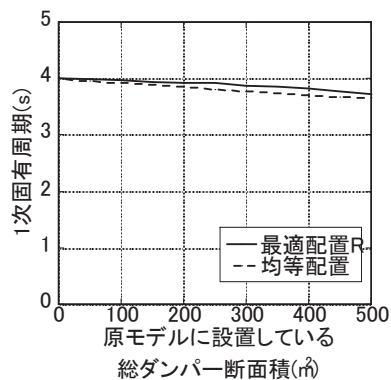

(a) 1 次

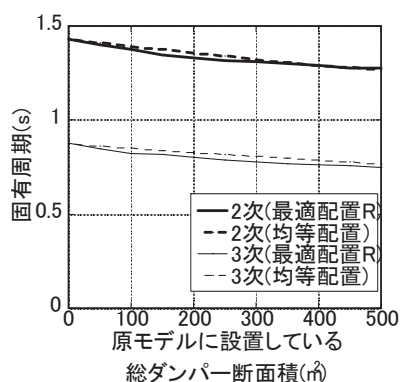

(b) 2 次及び 3 次

図 26 固有周期（原モデル）

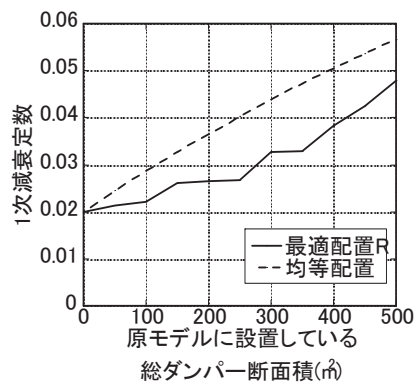

(a) 1 次

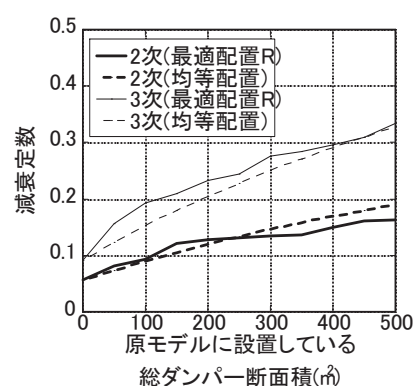

(b) 2 次及び 3 次

図 27 減衰定数（原モデル）

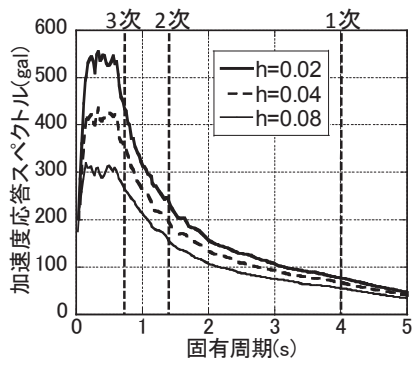

図 28 加速度応答スペクトル

(Newmark \& Hall レベル 1)

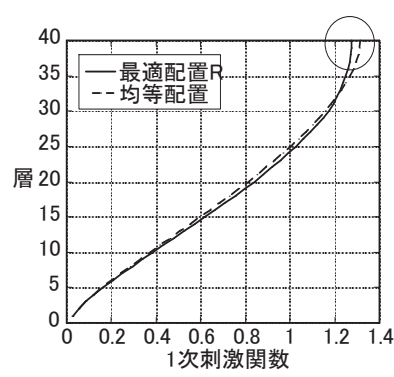

(a) 1 次

図 30 刺激関数（原千デル，紛ダンパー

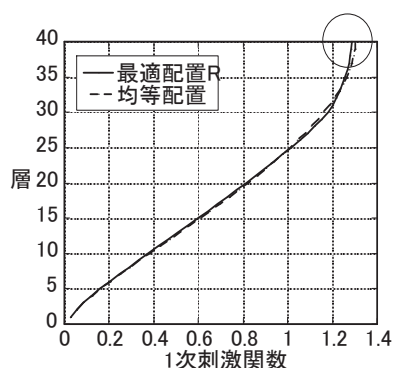

(a) 1 次

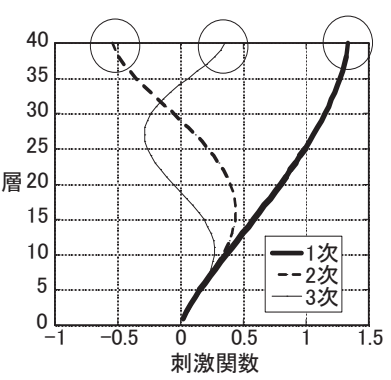

図 29 刺激関数

（原モデル，ダンパー無し）

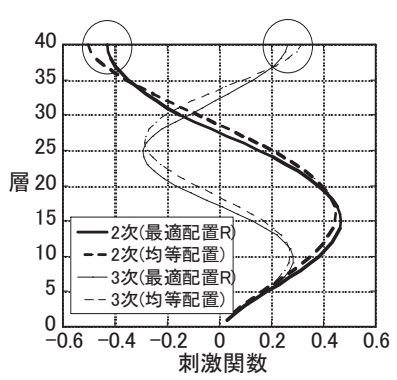

(b) 2 次及び 3 次

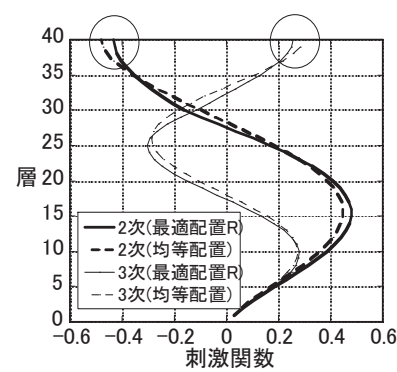

(b) 2 次及び 3 次
図 31 刺激関数（原モデル，総ダンパー断面積 $=500 \mathrm{~m}^{2}$ )
加速度の感度が近接するためであると考えられる。また図 24(b)より 最適配置 $\mathrm{R}$ と均等配置を比較すると, 最適配置 $\mathrm{R}$ の方が応答值が小 さい。従って, 頂部最大絶対加速度を最小化する場合においても, 本最適化手法は有効であると考えられる。

図 23 より, 頂部の最大絶対加速度を最小化する場合，5-3-1 節及 び 5-3-2 節の場合と異なり, 層間変位が小さい上層部にダンパーが 配置される傾向が見られる。この理由を固有周期, 減衰定数, 刺激 関数の点から考察する。図 26 より, 固有周期に関しては $1 \sim 3$ 次と もに最適配置と均等配置の差は僅かである。図 27 より, 減衰定数に ついては, 2, 3 次にはあまり差はないが, 1 次は均等配置の方が最 適配置より大きくなっている。これより均等配置の方が応答低減効 果が大きいと考えられる。

図 29〜31 にダンパー総断面積がそれぞれ $0 \mathrm{~m}^{2}, 250 \mathrm{~m}^{2}, 500 \mathrm{~m}^{2}$ の 場合の刺激関数を示す。それぞれの頂部刺激関数 (図の丸囲み部分) を比較すると，1 次についてはあまり差はないが，2，3 次について は, 最適配置の方が均等配置に比べ小さくなっている。すなわち, 均等配置に比べて最適配置の方がダンパーを高層部により多く配置 することで, 建物頂部の高次モードを抑えていることになる。ここ で, 図 28 の加速度応答スペクトルより, 1 次に比べ 2,3 次の方が加 速度応答に与える影響は大きいと考えられ，頂部最大絶対加速度を 最小化する場合に上層部に配置されたのは, 高次モードを抑える上 で効果が大きいからであると考えられる。

\section{6.まとめ}

1) 鈴木らが提案した風荷重を受ける非線形復元力を有する制振部 材付構造物の縮約法を拡張し, 地震動が入力された非線形復元力 を有する制振部材付構造物を層方向に縮約する方法を提案した。 また, 静的な意味での変位等価性条件から縮約モデルに作用する 縮約地震時慣性力を構築する方法を提案した。

2) 現実的な層剛性分布を有する構造物に高硬度ゴムダンパーを設 置した場合に対する縮約モデル及び縮約地震時慣性力を用いた 時刻歴応答解析から, 頂部最大水平変位及び特定層の最大層間変 位については, ダンパー量を増大させた時の原モデルの最大応答 值の変動を縮約モデルの解析結果を用いて精度よく表現できる ことを示した。

3) 1)で構築した縮約モデルに対して時刻歴応答解析を行い，対象と 寸る応答值の数值感度解析を行うことにより, 非線形復元力特性 を有する高硬度ゴムダンパーを構造物に最適設置する効率的か つ汎用性の高い方法を提案した。本論文では, 高硬度ゴムダンパ 一を一例としているが, 他のダンパーに対しても1)で示す縮約法 を利用すれば容易に適用可能である。

4) 模擬地震動群を入力とする 40 層せん断型構造物モデルを例とし て取り上げ, 頂部最大水平変位, 頂部最大絶対加速度及び最大層 間変位の最大值を最小化するダンパー配置を求めて, 縮約モデル を用いずに原モデルのみで行った最適配置の結果と比較し, 本最 適配置法が許容される精度を有しかつ有効であることを示した。 また，各層に同量のダンパーを設置した均等配置の場合と比べ, 本手法は有効な配置を効率よく提供できることを示した。

5) 4)で示した配置が最適な配置となる理由を, 頂部最大水平変位及 び最大層間変位の最大值を評価関数とする場合についてはダン 
パーの特性の点から, 頂部最大絶対加速度については固有周期, 減衰定数及び刺激関数の点から明らかにした。

本論文では，模擬地震動を用いて 4)で示した 3 種類の応答值をダン パー最適配置問題における目標関数としている。記録地震動につい ても, 縮約地震時慣性力の概念は有効であることを確認している ${ }^{17) 。}$ 今後記録地震動に対する本最適化手法の適用性について検討する必 要がある。特に，地震動の振動数特性が顕著な非単調性などを示す 場合には詳細な検討が必要である。

\section{謝辞}

本研究の一部は日本学術振興会の科学研究費補助金による （No.21360267）。ここに記して謝意を表す。

\section{参考文献}

1) Soong, T. T. and Dargush, G. F. : Passive energy dissipation systems in structural engineering, John Wiley \& Sons Ltd, 1997

2) Kasai, K, Munshi, J. A., Lai, M. L., and Maison, B. F. : Viscoelastic damper hysteretic model : theory, experiment and application, Proc. ATC-17-1 on Seismic Isolation, Energy Dissipation, and Active Control, Vol.2, pp521-532, 1993

3) 笠井和彦, 寺本道彦, 大熊潔, 所健 : 粘弾性体の温度 - 振動数 - 振幅依存 を考慮した構成則 その 1 線形領域における温度・振動数依存のモデル 化, 日本建築学会構造系論文集, No.543, pp77-86, 2001.5

4) Tsai, C. S. and Lee, H. H. : Application of viscoelastic dampers to highrise buildings, J. Structural Engineering, ASCE, 119(4), pp1222-1233, 1993

5) Tsuji, M. and Nakamura, T. : Optimum viscous dampers for stiffness design of shear buildings, J. Structural Design of Tall Buildings, Vol.5, pp217-234, 1996

6) Takewaki, I. : Optimal damper placement for minimum transfer functions, Earthq. Engrg. Struct. Dyn., Vol.26, pp1113-1124, 1997

7) 竹脇出: 地盤との連成を考慮した曲げ - せん断型構造物モデルの地震時有 効ダンパー配置法, 日本建築学会構造系論文集, No.530, pp77-84, 2000.4

8) 中川肇，浅野幸一朗：Poly-linear 型履歷ダンパーを用いた多層構造物の最 適地震応答制御について〜Poly-linear 型履歴ダンパーの最適剛性分布の評 価～，日本建築学会構造系論文集，No.530，pp45-51，2000.4

9) 笠井和彦, 湊直生, 桜井馨 : 粘弾性ダンパーの等価剛性調節による制振構 造の応答制御手法，日本建築学会構造系論文集，No.610，pp75-83，2006.12

10) 笠井和彦，小椋崇之，鈴木陽：非線形粘性ダンパーの等価剛性調節によ る制振構造の応答制御手法, 日本建築学会構造系論文集, No.618, pp97-104, 2007.8

11) 笠井和彦，岩崎啓介：様々な形式の制振構造における自由度縮約法と水 平バネ系への変換法, 日本建築学会構造系論文集, No.605, pp37-46, 2006.7

12) Wilson, E. L, Yuan, M. W., and Dickens, J. M. : Dynamic analysis by direct superposition of ritz vectors, Earthq. Engrg. Struct. Dyn., Vol.10, pp813-513, 1982

13) 鈴木ちひろ，辻聖晃，吉富信太，竹脇出：風外力を受ける超高層建築物 の逆問題型定式化に基づく時刻歴解析用縮約外力と縮約構造モデル，日 本建築学会構造系論文集, No.640, pp1073-1081, 2009.1

14) 谷翼, 辻聖晃, 吉富信太, 竹脇出, 松本達治：高硬度ゴム粘弾性体の力 学モデルの構築 その 1 極微小変形から大変形までの歪・振動数依存 性のモデル化, 日本建築学会構造系論文集, No.629, pp1079-1086, 2008.7

15) Tani, T., Yoshitomi, S., Tsuji, M., and Takewaki, I. : High-performance control of wind-induced vibration of high-rise building via innovative high-hardness rubber damper, J. Structural Design of Tall and Special Buildings, Vol.18, No.7, pp705-728, 2009

16) Nakamura, T. and Yamane, T. : Optimum design and earthquake-response constrained design of elastic shear buildings, Earthq. Engrg. Struct. Dyn., Vol.14, No.5, pp797-815, 1986.9

17）国分宏樹，吉富信太，辻聖晃，竹脇出：高硬度ゴムダンパーを付加した 建物の逆問題型手法に基づく縮約構造モデルと地震時慣性力の縮約法, 日本建築学会近畿支部研究報告集, pp89-92, 2009.6
18) Newmark, N. M. and Hall, W. J. : Earthquake Spectrum and Design, EERI, 1982 19) 鈴木ちひろ, 辻聖晃, 谷翼, 吉富信太, 竹脇出, 松本達治 : 高硬度ゴム 粘弾性ダンパーによる建物の風応答低減効果に関する実験的研究，日本 建築学会大会学術講演梗概集, 構造II, pp611-612, 2007.8

（2010年 3 月 5 日原稿受理，2010年 8 月 30 日採用決定） 